\title{
Risk Factors of Hypovitaminosis D in Adolescents, Shanghai, China: A Cross-Sectional Study
}

\author{
Chun-dan Gong ${ }^{1}$, Zheng Chen ${ }^{1}$, Qiao-ling Wu', Dan Zhang ${ }^{1}$, Zheng-yan Zhao ${ }^{2}$ and Yong-mei Peng ${ }^{1 *}$
}

${ }^{1}$ Department of Child Health Care, Children's Hospital of Fudan University, Shanghai 2011102, China

${ }^{2}$ Children's Hospital of Medical College of Zhejiang University, Zhejiang 310003, China

\begin{abstract}
Background and Objectives: Hypovitaminosis $D$ is prevalent worldwide. Accumulating researches suggested vitamin $\mathrm{D}$ deficiency is associated with obesity and dyslipidemia. But the relationship is still controversial. This study was aimed to evaluate the vitamin D status in Chinese adolescents, to find out the risk factors of hypovitaminosis $D$ and its association with obesity.

Methods: A cross-sectional survey of serum $25(\mathrm{OH}) \mathrm{D}$, glycolipids, anthropometric measurements and life style investigation was done in 441 youths. The prevalence of hypovitaminosis $D$ was determined. The influence factors of 25(OH)D concentration were analysed. Multi-variation logistic regression was utilized to find the risk factors of hypovitaminosis D. The association of vitamin D3 and the metabolic indice was analysed by gender.

Results: The mean serum 25(OH)D concentration was $21.9 \pm 8.1 \mathrm{ng} / \mathrm{ml}$. Boys had higher 25(OH)D than girls $(22.4 \pm 8.1 \mathrm{ng} / \mathrm{ml}$ vs. $19.0 \mathrm{ng} / \mathrm{ml}(\mathrm{P} 25: 15.5 \mathrm{ng} / \mathrm{ml}, \mathrm{P} 75: 25.2 \mathrm{ng} / \mathrm{ml}), \mathrm{p}<0.05)$. The prevalence of hypovitaminosis D was $42.4 \%$. The prevalence of vitamin $\mathrm{D}$ deficiency in girls was significantly higher than in boys $(55.4 \%$ vs. $39.8 \%$, $p<0.01)$. The mean concentration of $25(\mathrm{OH}) \mathrm{D}$ in winter was $19.6 \mathrm{ng} / \mathrm{ml}$, significantly lower than that in summer $(25.6 \pm$ $7.8 \mathrm{ng} / \mathrm{ml}, p<0.001)$. Significant differences were found in gender $(p=0.005)$, age $(p<0.001)$, BMI-SDS $(p=0.003)$, WCSDS $(p=0.005)$, seasons $(p<0.001)$ and NAFLD ratios $(p=0.018)$ among groups of vitamin $D$ sufficiency, insufficiency and deficiency. The logistic regression suggested that female $(O R=2.45, p=0.001)$, older ages $(O R=1.29, p=0.011)$ and winter $(O R=1.96, p=0.038)$ were risk factors of vitamin $D$ deficiency. In male adolescents, $H D L$ was protective factor of $25(\mathrm{OH}) \mathrm{D}$ concentrations $(\mathrm{OR}=0.22, \mathrm{p}=0.009)$. BMI and WC were of no association with vitamin $\mathrm{D}$. No relationship between $25(\mathrm{OH}) \mathrm{D}$ and metabolic indice or anthropometric measurements in girls was found.

Conclusions: The vitamin D3 status in adolescents was very worrying. The risk factors of hypovitaminosis D were female, older ages and winter. 25(OH)D concentration had no relationship with BMI, WC, NAFLD in both genders.
\end{abstract}

Keywords: Adolescents; Children; 25(OH)D; Vitamin $\mathrm{D}_{3}$; BMI; Glycolipid metabolism

Abbreviations: 25(OH)D: 25-Hydroxyvitamin D; BMI-SDS: Body Mass Index Standard Deviation Score; WC: Waist Circumstance; WC-SDS: Waist Circumstance Standard Deviation Score; NAFLD: Nonalcoholic Fatty Liver Disease; HDL: High Density Lipoprotein Cholesterol; LDL: Low-Density Lipoprotein Cholesterol; TG: Triglyceride; TC: Total Cholesterol; HOMA-IR: Homeostasis Model Assessment Of Insulin Resistance

\section{Introduction}

The Vitamin D endocrine system plays several important roles in human's body, such as bone health, keratinocyte differentiation and immune system [1]. Accumulating research suggests vitamin D deficiency is high risk factors of obesity, diabetes and cardiovascular disease. It also has been extensively studied in other diseases such as breast cancer [2], systemic lupus erythematosus [3], asthma [4] etc.

Vitamin D can be obtained from nutritional origin or be synthesized by skin under sun exposure. But few natural foods contain vitamin $\mathrm{D}$, including deep fish oil. And lack of the knowledge that sun exposure is the major source of vitamin $\mathrm{D}$ also is the main cause of vitamin $\mathrm{D}$ deficiency [5].

Hypovitaminosis D is prevalent worldwide. $37.4 \%$ healthy children in Canada had insufficient vitamin D status [6]. A survey carried out in Korea showed that $71 \%$ adolescents had vitamin D3 deficiency [7]. $51.2 \%$ of boys living in San Antonio los Cobres had severe vitamin D deficiency and no one had optimal vitamin $\mathrm{D}$ in a research carried out by Hirschler et al. [8]. A population-based survey in Greenland showed that vitamin D status was affected by diet pattern and ethnicity [9].

In China, there was no national survey on population's vitamin $\mathrm{D}$ status. But some regional studies have been carried out. Compared to the large body of adults' researches, investigations focused on children was relatively smaller. A survey carried out among 1-month to 16-yearold children showed that the total prevalence of hypovitaminosis D was $5.4 \%$ but increased with age ( $46.4 \%$ at $12-16$ age stage) [10]. Another analysis focused on adolescent girls showed that $57.8 \%$ of subjects were vitamin D deficient [11]. To update, there has been no survey carried out in adolescents in Shanghai, which is the most economically advanced city in China and with lots of high buildings which may influence the exposure to sunlight. And the association between vitamin $\mathrm{D}$ and anthropometry or glycolipids hasn't been explored, neither. Thus in the present study, the serum of $25(\mathrm{OH}) \mathrm{D}$ and glycolipid profile of both adolescent boys and girls were investigated. It aimed to find out the risk factors of vitamin D deficiency and whether it was associated with

*Corresponding author: Yong-mei Peng, Department of Child Health Care, Children's Hospital of Fudan University, 399 Wanyuan Road, Shanghai 201102, China, Tel: +86 2164931229, Fax: +86 2164043900; E-mail: ympeng@fudan.edu.cn

Received March 31, 2015; Accepted April 20, 2015; Published April 25, 2015

Citation: Gong C, Chen Z, Wu Q, Zhang D, Zhao Z, et al. (2015) Risk Factors of Hypovitaminosis D in Adolescents, Shanghai, China: A Cross-Sectional Study. J Nutr Disorders Ther 5: 158. doi:10.4172/2161- 0509.1000158

Copyright: (c) 2015 Gong C, et al. This is an open-access article distributed under the terms of the Creative Commons Attribution License, which permits unrestricted use, distribution, and reproduction in any medium, provided the original author and source are credited. 
glucose and lipids metabolism. Therefore, it may help to make options to ameliorate the status of vitamin D deficiency.

\section{Subjects and Methods}

\section{Subjects}

Fifteen elementary and junior high schools in Shanghai's two districts were chosen by using cluster sampling. The details of sampling were described elsewhere [12]. The flow diagram was shown in (Figure 1). Briefly, after primary survey on body weight and height, 9- to 15-year-old adolescents with normal weight and high body mass index (BMI) were equally recruited in this study. The inclusion criteria conclude that the subjects should be single birth, without congenital diseases, chromosome abnormality, hereditary metabolic diseases and abnormal skeletal development. Totally 441 students having complete data of physical examinations and serum 25(OH)D concentrations were included in this research. The research was carried out in two batches (Nov. 2011 to Jan. 2012(winter), July to Aug. 2012(summer)). Signed informed consent was obtained from each child's parent or guardian. Ethical approval was obtained from ethics committee of Children's Hospital of Fudan University.

\section{Anthropometric measurements}

Team members of this study were trained before research. Body weight and height were obtained using Seca stadiometer and electronic scale, with the participants wearing light underwear and barefoot. Waist circumference was measured at the narrowest point between the lower border of the rib cage and the iliac crest. Body mass index (BMI) was calculated according to the equation: $\mathrm{BMI}=$ body weight $(\mathrm{kg}) /$ height ${ }^{2}\left(\mathrm{~m}^{2}\right)$. As BMI and WC change with age and sex, BMI standard deviation score (BMI-SDS) and WC standard deviation score (WCSDS) were calculated by LMS method [13] for each one according to the references of BMI and WC distribution of Chinese children and adolescents $[14,15]$. Physical examination was performed to evaluate the participants' health status. Non-alcoholic fatty liver disease (NAFLD) was identified by ultrasonography and recorded as absent, mild, moderate and severe [16]. The examination was performed by a same radiologist using Premier-Siemens equipment.

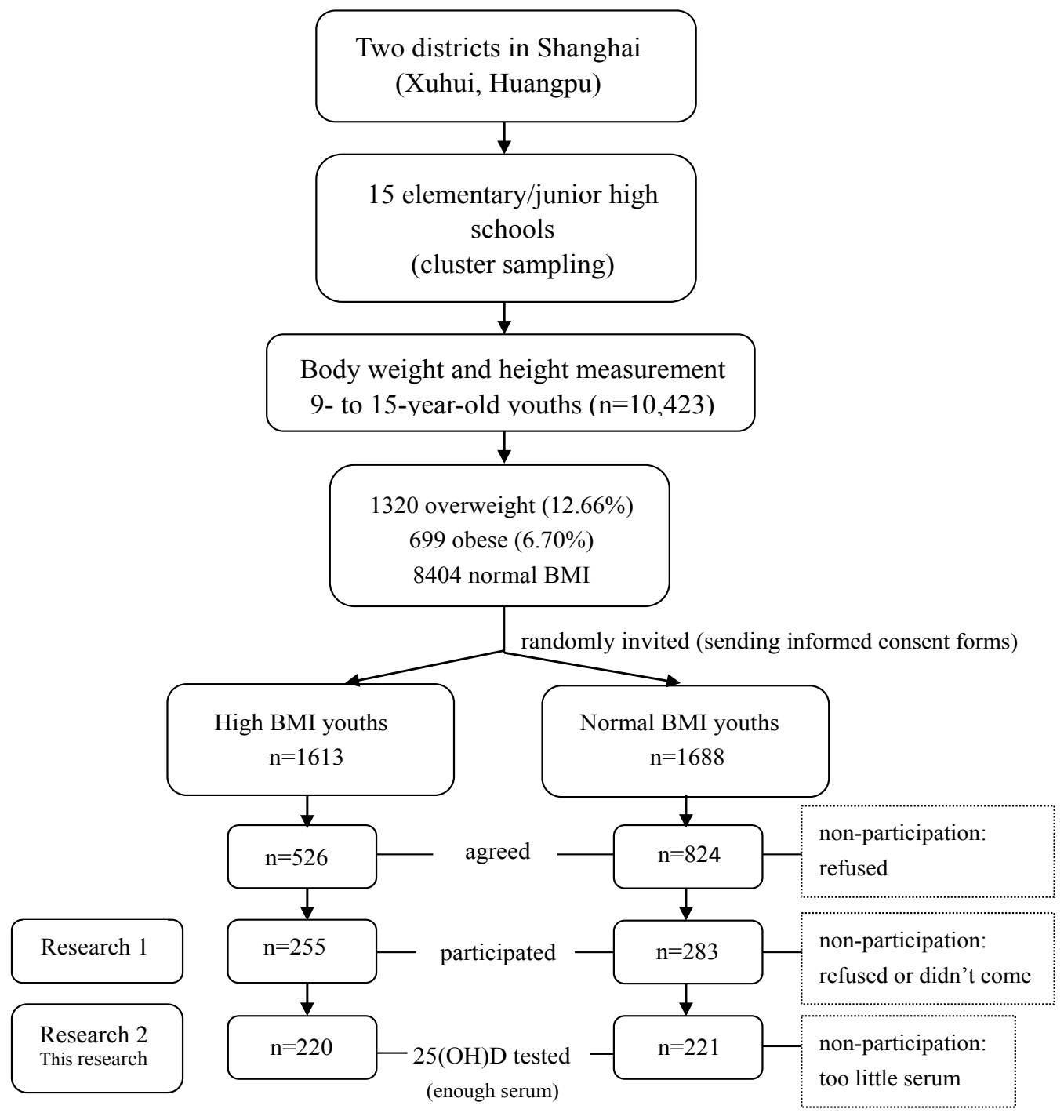

Figure 1: The flow diagram of the study population included. 


\section{Life style investigation}

Questionnaires about physical activities and dietary habits were filled out collaborated by the children and their guardians. The questionnaire contained the questions like: How does your child go to school? What's the frequency of physical education lessons every week? Any other sport activities like running, swimming, basketball? Does your child prefer eating meat or vegetable? How much milk does your child consume? Does your child take nutritional supplements? What kind and how much?

\section{Biochemical measurements}

Blood samples were taken from the participants after at least 8 -hour fast. Serum were obtained by centrifuging and stored at $-80^{\circ} \mathrm{C}$. Serum $25(\mathrm{OH}) \mathrm{D}$ concentrations were measured by electrochemical purchased from Roche Diagnostics GmbH (Mannhein, Germany). The coefficients of variation (CV) of intra-assay and intermediate precision were $\leq 7.5 \%$ and $\leq 13.6 \%$. Total cholesterol (TC), triglyceride (TG), high density lipoprotein cholesterol (HDL), low density lipoprotein cholesterol (LDL), glucose were tested by standard methods using a Hitachi 7180 analyzer (Hitachi High Technologies Corp, Tokyo, Japan). The CVs of intra-assay were less than $8 \%$ and inter-assay less than $10 \%$ for all the items. Electrochemical Luminescence was used to measure insulin and peptide $\mathrm{C}$ by Roche E601 analyzer. The CVs of intra-assay and intermediate precision were $\leq 1.5 \%$ and $\leq 4.9 \%$ for insulin, $\leq 4.6 \%$ and $\leq 5.0 \%$ for peptide C.

\section{Diagnose of Obesity and Overweight}

Obesity was defined on the basis of BMI above the $95^{\text {th }}$ percentile for age and gender on the BMI percentile charts for Chinese children and adolescents and overweight above the $85^{\text {th }}$ percentile [17].

\section{Vitamin D Status}

Vitamin D status was judged by the serum concentration of $25(\mathrm{OH})$ $\mathrm{D}$ and graded as sufficiency: $>75 \mathrm{nmol} / \mathrm{L}(30 \mathrm{ng} / \mathrm{ml})$, insufficiency: 50 $75 \mathrm{nmol} / \mathrm{L}(20-30 \mathrm{ng} / \mathrm{ml})$, deficiency: $<50 \mathrm{nmol} / \mathrm{L}(20 \mathrm{ng} / \mathrm{ml})$ and severe deficiency: $<25 \mathrm{nmol} / \mathrm{L}(10 \mathrm{ng} / \mathrm{ml})$ [5].

\section{Statistical Analyses}

SSPS 19.0 was used to perform statistical analysis. Mean \pm standard deviation of data was given for normally-distributed variables. Median, interquartile range was given for non-normally distributed data. luminescence using Roche E411 analyzer and vitamin D total kit was

ANOVA or Kruskal-Wallis $\mathrm{H}$ test was used to compare the means among groups. Chi-square test was used to compare the prevalence of NAFLD among different groups. Multivariate logistic regression was utilized to find the risk factors of hypovitaminosis D. Missing data was not included in statistical analysis and the number of missing data was listed in tables.

\section{Results}

\section{The characteristic of the study population}

Four hundred and forty-one adolescents participated in this research, among which 284 boys and 157 girls. Three hundred and thirty-eight were examined during Nov. 2011 and Jan. 2012(winter) and 103 during Oct. 2011 and July 2012 (summer). The mean age was 12 years old. Average BMI was $22.0 \pm 4.7 \mathrm{~kg} / \mathrm{m}^{2}$ and boys had higher BMI than girls. It was of no significant difference between the mean value of BMI-SDS of boys and girls. The median WC-SDS of boys was 1.18, significantly higher than that of girls $(0.8 \pm 1.0, \mathrm{p}=0.029)$. No statistical difference of physical activities was found between males and females (Table 1).

\section{Vitamin D status of the study population}

The mean concentration of serum $25(\mathrm{OH}) \mathrm{D}$ in the whole population was $21.9 \pm 8.1 \mathrm{ng} / \mathrm{ml}$ (Table 1). Forty-two point four percent of the adolescents were vitamin $\mathrm{D}$ deficient, with $3.0 \%$ being severe deficient. Only $17.2 \%$ of the population had optimal $25(\mathrm{OH}) \mathrm{D}$ concentration.

\section{Difference of 25(OH)D between gender}

Compared to the boys' $(22.4 \pm 8.1 \mathrm{ng} / \mathrm{ml})$, girls had much lower 25(OH)D concentration $(19.0 \mathrm{ng} / \mathrm{ml}(15.5 \mathrm{ng} / \mathrm{ml}, 25.2 \mathrm{ng} / \mathrm{ml}), \mathrm{p}<0.05)$. The prevalence of vitamin $\mathrm{D}$ deficiency in male and female adolescents was shown in (Figure 2). It was $55.41 \%$ in girls, significantly higher than that in boys $(\mathrm{p}<0.005)$. More boys were vitamin $\mathrm{D}$ insufficient while more girls were deficient. Only $18.0 \%$ in boys and $16.0 \%$ in girls had ideal vitamin D status.

\section{Differences of 25(OH)D among ages}

The concentrations of $25(\mathrm{OH}) \mathrm{D}$ decreased with ages (Figure 3 ). The concentration of $25(\mathrm{OH}) \mathrm{D}$ in adolescents aged 10- to 12 -year-old was about $23.0 \mathrm{ng} / \mathrm{ml}$, while that of adolescents aged 13- to 15-year-old was below $20.0 \mathrm{ng} / \mathrm{ml}$, which was significantly lower than the former.

\section{Fluctuation of 25(OH)D among seasons}

The $25(\mathrm{OH}) \mathrm{D}$ concentration of subjects examined in winter was

\begin{tabular}{|c|c|c|c|c|}
\hline Variables & $\begin{array}{c}\text { Total } \\
n=441\end{array}$ & $\begin{array}{c}\text { Male } \\
\mathrm{n}=284\end{array}$ & $\begin{array}{c}\text { Female } \\
n=157\end{array}$ & $\mathbf{p}$ \\
\hline Age (y) & $12(11,13)^{2}$ & $12(11,13)$ & $12(12,13)$ & 0.683 \\
\hline Body weight (kg) & $53.0(45.6,65.0)$ & $58.0 \pm 16.6$ & $51.7 \pm 12.0$ & $<0.001$ \\
\hline Body height (cm) & $158.5 \pm 10.23$ & $159.7 \pm 11.3$ & $156.3 \pm 7.3$ & $<0.001$ \\
\hline BMI $\left(\mathbf{k g} / \mathbf{m}^{2}\right)$ & $22.0 \pm 4.7$ & $22.5 \pm 4.9$ & $21.1 \pm 4.2$ & 0.002 \\
\hline BMI-SDS & $1.0 \pm 1.2$ & $1.0 \pm 1.3$ & $1.0 \pm 1.2$ & 0.620 \\
\hline WC (cm) & $71.6(65.0,81.0)$ & $75.7 \pm 12.0$ & $69.3 \pm 8.8$ & $<0.001$ \\
\hline WC-SDS & $1.1(0.2,1.7)$ & $1.2(0.3,1.7)$ & $0.8 \pm 1.0$ & 0.029 \\
\hline 25(OH)D (ng/ml) & $21.9 \pm 8.1$ & $22.4 \pm 8.1$ & $19.0(15.5,25.2)$ & 0.048 \\
\hline Physical exam time (min/w) & $\begin{array}{c}290(221,360) \\
(n=435)\end{array}$ & $\begin{array}{c}287(220,373) \\
(n=279)\end{array}$ & $\begin{array}{c}290(234,343) \\
(n=156)\end{array}$ & 0.647 \\
\hline
\end{tabular}

${ }^{1}$ Kruskal-Wallis $\mathrm{H}$ test or $\mathrm{t}$ test were used to determine differences for continuous and categorical variables between male and female. NAFLD, nonalcoholic fatty liver disease.

${ }^{2}$ Medians, interquartile ranges in parentheses (all such values).

${ }^{3}$ Mean \pm SD (all such values). 


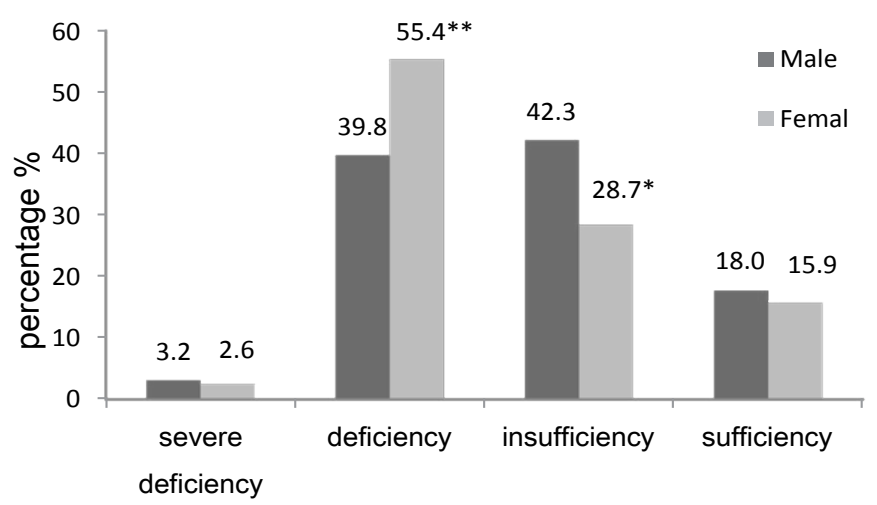

25(OH)D concentration catagories

Male vs. Female: ${ }^{* *} p<0.005,{ }^{*} p<0.05$ (Chi-square test)

Figure 2: The distribution of vitamin $\mathrm{D}$ concentrations in boys and girls.

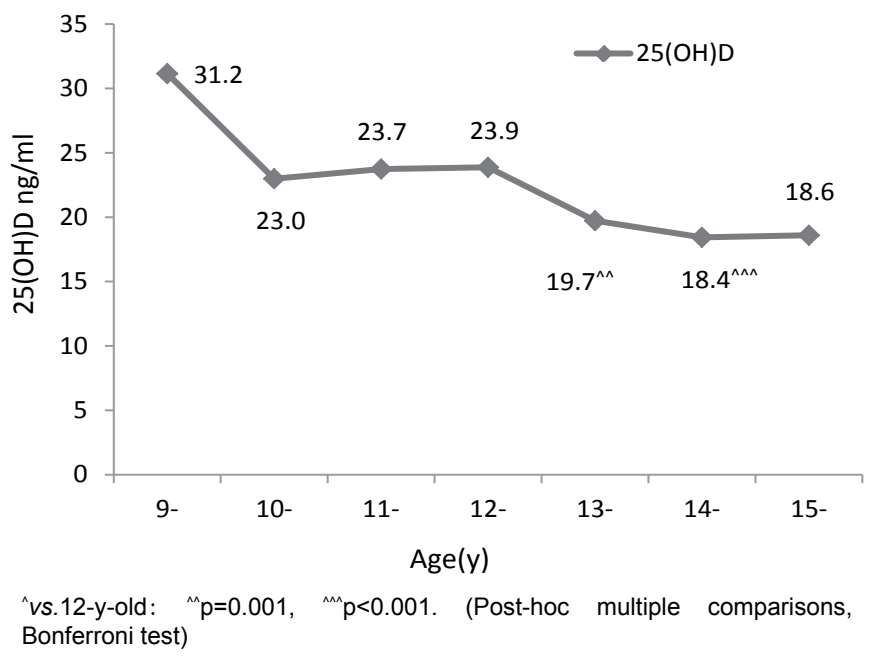

Figure 3: The fluctuation of serum 25(OH)D with ages in adolescents.

$19.6 \mathrm{ng} / \mathrm{ml}$, significantly lower than the mean value in summer $(25.6$ $\pm 7.8 \mathrm{ng} / \mathrm{ml}, \mathrm{p}<0.001)$. The fluctuation of $25(\mathrm{OH}) \mathrm{D}$ concentration in different months were shown in (Figure 4). December and January showed the lowest concentrations, while November and July presented higher values. Hypovitaminosis D prevalence also showed the same fluctuation with months (Figure 5). More than half adolescents had vitamin D deficiency in the two coldest months (Nov and Jan).

\section{Influence factors of $25(\mathrm{OH}) \mathrm{D}$ concentration}

The subjects were divided into three groups depending on the serum 25(OH)D concentration: deficiency, insufficiency and sufficiency. Univariate analyses were done to explore factors' (like gender, age, BMI, season, etc.) associations with 25(OH)D status (Table 2). The median age of deficient subjects was significantly higher than that of indeficient ones (13 vs. $12, \mathrm{p}<0.001)$. More girls than boys were likely to be vitamin $\mathrm{D}$ deficient ( $\mathrm{p}=0.005)$. The mean BMI of deficient group was $23.0 \pm 5.2 \mathrm{~kg} / \mathrm{m}^{2}$, significantly higher than that of insufficient and sufficient groups $\left(21.5 \pm 4.1 \mathrm{~kg} / \mathrm{m}^{2}, 20.4 \pm 3.9 \mathrm{~kg} / \mathrm{m}^{2}, \mathrm{p}<0.001\right)$. The median waist circumstance of deficient group was higher than indeficient group $(\mathrm{p}=0.001)$. The ratio of vitamin $\mathrm{D}$ deficiency in winter was higher than in summer $(\mathrm{p}<0.001)$. The prevalence of NAFLD in deficient group was $19.0 \%$, higher than that of insufficient (15.8\%) and sufficient $(5.3 \%)$ group $(\mathrm{p}=0.018)$. The total physical activity time per week was of no statistical difference among the three groups $(\mathrm{p}=0.751)$ and neither was the way to go to school.

As to dietary habits, the frequency of taking milk differed between the three groups $(\mathrm{p}=0.033)$. Preference to vegetable or meat didn't differ among groups. The frequencies of taking yoghurt, meat, egg and fish didn't differ among three groups. In the whole population, 58.7\% subjects never took vitamin supplements. The ratios of subjects never taking supplements of calcium, zinc, iron and folic acid were up to $64.4 \%-73.2 \%$. Only $4.1 \%$ children take vitamin supplements every day.

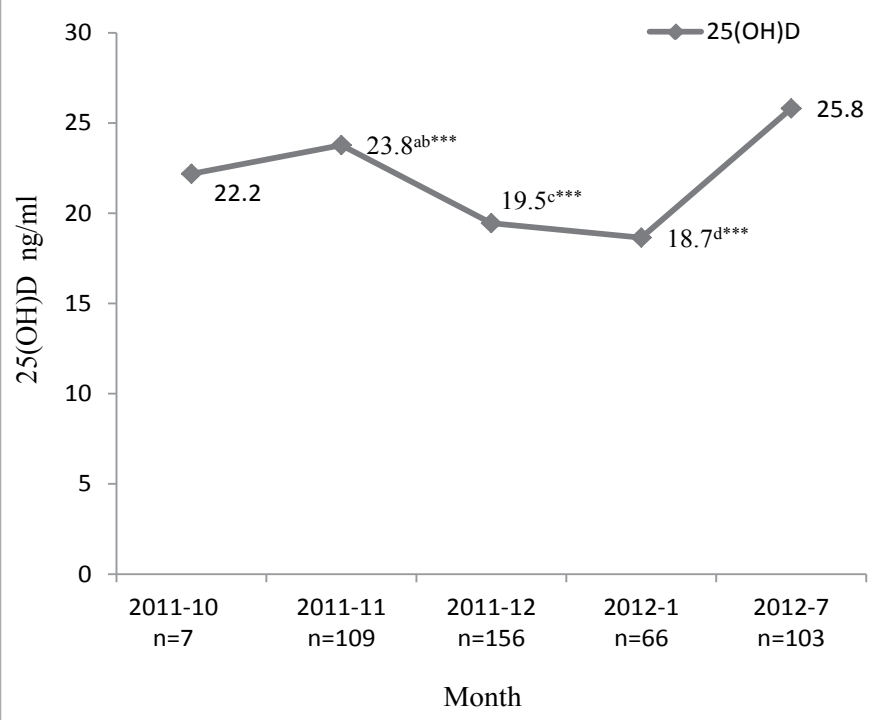

a 2011-11 vs.2011-12 b2011-11vs. 2012-1

c 2011-12 vs. 2012-7 d 2012-1 vs. 2012-7

*** $p<0.001$

December and January showed the lowest concentrations, while November and July presented higher values. (Post-hoc multiple comparisons, Bonferroni test)

Figure 4: The fluctuation of serum 25(OH)D with seasons in adolescents.

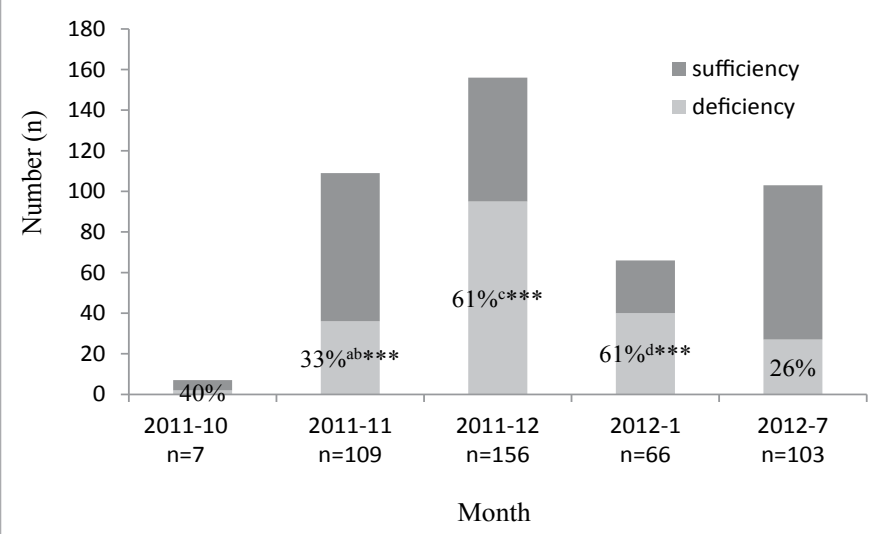

a 2011-11 vs. 2011-12 b 2011-11 vs. 2012-1

c 2011-12 vs. 2012-7 d 2012-1 vs. 2012-7

${ }_{* * *} p<0.001$ (Chi-square test)

Figure 5: The distribution of vitamin $D$ categories in different months in adolescents. 


\begin{tabular}{|c|c|c|c|c|}
\hline Variables & $\begin{array}{l}\text { Deficiency } \\
n=200\end{array}$ & $\begin{array}{c}\text { Insufficiency } \\
n=165\end{array}$ & $\begin{array}{c}\text { Sufficiency } \\
n=76\end{array}$ & $\mathbf{p}$ \\
\hline 25(OH)D (ng/ml) & $14.9 \pm 3.1^{2}$ & $24.3 \pm 2.8$ & $35.2 \pm 4.5$ & $<0.001$ \\
\hline Age (yr) & $13(12,14)^{3}$ & $2(11,13)$ & $12(11,12)$ & $<0.001$ \\
\hline Gender (M/F) & $113 / 87$ & $120 / 45$ & $51 / 25$ & 0.005 \\
\hline BMI $\left(\mathbf{k g} / \mathbf{m}^{2}\right)$ & $23.0 \pm 5.2$ & $21.5 \pm 4.1$ & $20.4 \pm 3.9$ & $<0.001$ \\
\hline BMI-SDS & $1.2 \pm 1.3$ & $1.0 \pm 1.2$ & $0.6 \pm 1.2$ & 0.003 \\
\hline WC (cm) & $73.2(66.0,83.5)$ & $72.4 \pm 11.7$ & $69.3 \pm 9.8$ & 0.001 \\
\hline WC-SDS & $1.0 \pm 1.0$ & $0.9 \pm 0.9$ & $0.6 \pm 1.0$ & 0.005 \\
\hline $\begin{array}{l}\text { Seaso } \\
\text { Summ }\end{array}$ & $171 / 29$ & $115 / 50$ & $45 / 31$ & $<0.001$ \\
\hline NAFLD (\%) & $\begin{array}{c}19.6 \\
(n=194)\end{array}$ & $\begin{array}{c}16.0 \\
(n=163)\end{array}$ & $\begin{array}{c}5.3 \\
(n=75)\end{array}$ & 0.016 \\
\hline $\begin{array}{l}\text { Transport } \\
\text { (walking+ } \\
\text { car) }\end{array}$ & 119/72 & $81 / 79$ & $41 / 33$ & 0.086 \\
\hline PE time ( $r$ & $\begin{array}{c}285(220,350) \\
\quad(n=193)\end{array}$ & $\begin{array}{c}280 \\
(227.5,367.5) \\
(n=159)\end{array}$ & $305(212.5,370)$ & 0.751 \\
\hline $\begin{array}{l}\text { Dietary pattern } \\
(1 / 2 / 3)^{4}\end{array}$ & $50 / 138 / 5$ & $53 / 108 / 3$ & $20 / 54 / 2$ & 0.710 \\
\hline \multicolumn{5}{|c|}{$\begin{array}{l}{ }^{1} \text { ANOVA, chi-square test or Kruskal-Wallis } \mathrm{H} \text { test were to determine difference } \\
\text { for continuous and categorical variables among three groups. NAFLD, } \\
\text { nonalcoholic fatty liver disease. } \\
{ }^{2} \text { Mean } \pm \text { SD (all such values). } \\
{ }^{3} \text { Medians, interquartile ranges in parentheses (all such values). } \\
{ }^{4} \text { Dietary pattern: } 1=\text { meat-based, } 2=\text { vegetable-meat-balanced, } 3=\text { vegetable- } \\
\text { based }\end{array}$} \\
\hline
\end{tabular}

Table 2: The anthropometric indice and life styles in different serum 25(OH)D groups.

Less than $5 \%$ of the subjects take the supplements mentioned above every day. The frequencies of taking supplements did not differ among groups $(\mathrm{p} \geq 0.05)$.

With the variables of statistical difference among groups included, multivariate logistic regression analysis was performed (Table 3). It determined that the risk factors of vitamin $\mathrm{D}$ deficiency was gender $(\mathrm{OR}=2.45, \mathrm{p}=0.001)$, age $(\mathrm{OR}=1.29, \mathrm{p}=0.011)$ and season $(\mathrm{OR}=1.96$, $\mathrm{p}=0.038$ ). It presented that female and older children were likely to be vitamin $\mathrm{D}$ deficient. In winter, children were inclined to be hypovitaminosis $\mathrm{D}$.

\section{Associations between 25(OH)D and glycolipids}

It had been found out that there were differences between boys and girls as to glycolipid metabolism [16]. The results of multivariate logistic regression analysis described above also showed that the associations of $\mathrm{BMI}$ or WC with vitamin D status were influenced by gender. So the analysis was done by gender separately.

The anthropometry parameters and biochemical measurements of boys with different $25(\mathrm{OH}) \mathrm{D}$ concentrations were listed in (Table 4). There were significant differences of BMI and WC among different 25(OH)D categories. Except of HDL, no statistical differences were found of TC, TG, LDL, insulin and HOMA-IR among groups. After including these four variables in multivariate logistic regression analysis, only HDL showed association with vitamin D status $(\mathrm{OR}=0.22,95 \% \mathrm{CI}$ 0.07-0.69, $\mathrm{p}=0.009$ ). BMI, WC and NAFLD were no longer associated with vitamin $\mathrm{D}$.

It was of no significant difference of girls' BMI, WC, TC, insulin and NAFLD among different 25(OH)D categories (Table 5).

\section{Discussion}

The results of this research showed that the vitamin D status in Chinese adolescents was very worrying. The mean concentration was $21.9 \pm 8.1 \mathrm{ng} / \mathrm{ml}$, lower in girls. $42.4 \%$ adolescents in the population were vitamin $\mathrm{D}$ deficient. It was close to the results of an investigation done in paediatric population in Hangzhou, China [10]. The survey investigated the $25(\mathrm{OH}) \mathrm{D}$ concentration in 6,008 children aged 1 -month to 16 -year-old. The ratio of hypovitaminosis $\mathrm{D}$ was $46.4 \%$ in adolescents aged 12- to 16-year-old, which was close to this study.

Older children were more likely to be hypovitaminosis D. This phenomenon was also reported by other researches. CA Stoian's [6] results showed that the odds ratio of children aged 9-13-year-old to be suboptimal vitamin D was 2.49 (95\%CI: 1.72-3.59, $\mathrm{p}<0.001$ ) compared with children aged 2-4.99-year-old. In Zhu's study mentioned above [10], infants had the highest $25(\mathrm{OH}) \mathrm{D}$ concentration $(98.7 \pm 47.1$ $\mathrm{nmol} / \mathrm{L}$ ) and the mean concentration of $25(\mathrm{OH}) \mathrm{D}$ decreased from 69.6 $\pm 30.4 \mathrm{nmol} / \mathrm{L}$ in 2 -5-year-old toddlers, $56.1 \pm 19.9 \mathrm{nmol} / \mathrm{L}$ in 6 - 11 -yearold children to $52.1 \pm 17.0 \mathrm{nmol} / \mathrm{L}$ in 12 -16-year-old adolescents. The high concentration of $25(\mathrm{OH}) \mathrm{D}$ in infants and toddlers may due to the routine supplementation of vitamin $\mathrm{D}$. In this study the decreasing tendency of $25(\mathrm{OH}) \mathrm{D}$ with age may cause by shrinking outdoor activities due to heavy school work and sunscreen cream using in girls. Further researches are needed to identify the reasons.

The finding of association between vitamin $\mathrm{D}$ and seasons was recognized in a large body of researches. The potential essence was the association with sunlight exposure. The sunlight alternates with seasons

\begin{tabular}{|c|c|c|}
\hline Variables & $\mathbf{p}$ & OR(95\% CI) \\
\hline Gender & 0.002 & $2.22(1.35,3.65)$ \\
\hline Age & 0.001 & $1.42(1.16,1.74)$ \\
\hline BMI-SDS & 0.441 & $1.20(0.76,1.90)$ \\
\hline WC-SDS & 0.748 & $1.10(0.62,1.94)$ \\
\hline Season & 0.037 & $2.00(1.04,3.83)$ \\
\hline Milk intake frequency & 0.122 & $0.88(0.74,1.04)$ \\
\hline NAFLD & 0.112 & $1.47(0.91,2.37)$ \\
\hline
\end{tabular}

Table 3: Multivariate logistic regression analysis of the risk factors of vitamin $D$ deficiency.

\begin{tabular}{|l|c|c|c|c|}
\hline Variables & $\begin{array}{c}\text { Deficiency } \\
(\mathbf{n = 1 1 3 )}\end{array}$ & $\begin{array}{c}\text { Insufficiency } \\
(\mathbf{n = 1 2 0 )}\end{array}$ & $\begin{array}{c}\text { Sufficiency } \\
(\mathbf{n = 5 1 )}\end{array}$ & $\mathbf{p}$ \\
\hline BMI (kg/m $\mathbf{2})$ & $24.1 \pm 5.5^{2}$ & $21.8 \pm 3.9$ & $20.4 \pm 4.3$ & $<0.001$ \\
\hline WC (cm) & $79.9 \pm 13.0$ & $73.7 \pm 12.0$ & $69.8 \pm 10.7$ & $<0.001$ \\
\hline TC (mmol/L) & $4.2 \pm 0.8$ & $4.2 \pm 0.6$ & $4.3 \pm 0.7$ & 0.586 \\
\hline TG (mmol/L) & $0.9(0.6,1.2)^{3}$ & $0.8(0.6,1.0)$ & $0.7(0.6,1.1)$ & 0.387 \\
\hline HDL (mmol/L) & $1.3 \pm 0.2$ & $1.5 \pm 0.3$ & $1.6 \pm 0.3$ & $<0.001$ \\
\hline LDL (mmol/L) & $2.5 \pm 0.7$ & $2.4 \pm 0.6$ & $2.4 \pm 0.7$ & 0.702 \\
\hline Glu (mmol/L) & $5.0 \pm 0.4$ & $5.0 \pm 0.5$ & $5.0 \pm 0.5$ & 0.591 \\
\hline Insulin ( $\boldsymbol{\mu l U} / \mathbf{m l})$ & $6.9(4.4,11.3)$ & $7.0(4.9,10.8)$ & $6.5 \pm 2.8$ & 0.815 \\
\hline HOMA-IR & $1.5(1.0,2.6)$ & $1.6(1.0,2.4)$ & $1.5 \pm 0.7$ & 0.879 \\
\hline NAFLD (\%) & 27.3 & 19.3 & 5.9 & 0.007 \\
\hline
\end{tabular}

${ }^{1}$ ANOVA, chi-square test or Kruskal-Wallis $\mathrm{H}$ test were to determine differences for continuous and categorical variables among three groups. NAFLD,

nonalcoholic fatty liver disease; HOMA-IR, homeostasis model assessment of insulin resistance.

${ }^{2}$ Mean \pm SD (all such values).

${ }^{3}$ Medians, interquartile ranges in parentheses (all such values).

Table 4: The anthropometric indice and glycolipids of boys in different serum 25(OH)D groups. 


\begin{tabular}{|c|c|c|c|c|}
\hline Variables & $\begin{array}{l}\text { Deficiency } \\
\quad(n=87)\end{array}$ & $\begin{array}{c}\text { Insufficiency } \\
(n=45)\end{array}$ & $\begin{array}{l}\text { Sufficiency } \\
\quad(n=25)\end{array}$ & $\mathbf{p}$ \\
\hline BMI $\left(\mathbf{k g} / \mathbf{m}^{2}\right)$ & $21.4 \pm 4.4^{2}$ & $20.7 \pm 4.5$ & $20.4 \pm 3.0$ & 0.448 \\
\hline WC (cm) & $69.6 \pm 8.5$ & $69.1 \pm 10.1$ & $68.3 \pm 7.9$ & 0.793 \\
\hline $\mathrm{TC}(\mathrm{mmol} / \mathrm{L})$ & $4.3 \pm 0.8$ & $4.4 \pm 0.6$ & $4.2 \pm 0.7$ & 0.510 \\
\hline TG (mmol/L) & $0.8(0.6,1.0)^{3}$ & $0.8 \pm 0.3$ & $0.9 \pm 0.3$ & 0.314 \\
\hline HDL (mmol/L) & $1.5 \pm 0.3$ & $1.6 \pm 0.3$ & $1.5 \pm 0.2$ & 0.389 \\
\hline LDL (mmol/L) & 2. $5 \pm 0.6$ & $2.5 \pm 0.5$ & $2.4 \pm 0.6$ & 0.841 \\
\hline Glu (mmol/L) & $4.8 \pm 0.4$ & $4.7 \pm 0.4$ & $4.7 \pm 0.3$ & 0.440 \\
\hline Insulin ( $\mu \mathrm{lU} / \mathrm{ml})$ & $6.5(4.7,9.6)$ & $8.3 \pm 6.6$ & $6.8 \pm 2.0$ & 0.844 \\
\hline HOMA & $1.4(1.0,2.0)$ & $1.4(0.9,2.2)$ & $1.4 \pm 0.4$ & 0.857 \\
\hline NAFLD (\%) & $\begin{array}{c}8.7 \\
(n=84)\end{array}$ & $\begin{array}{c}6.8 \\
(n=44)\end{array}$ & $\begin{array}{c}4.2 \\
(n=24)\end{array}$ & 0.740 \\
\hline
\end{tabular}

${ }^{1}$ ANOVA, chi-square test or Kruskal-Wallis $\mathrm{H}$ test were to determine differences for continuous and categorical variables among three groups. NAFLD, nonalcoholic fatty liver disease; HOMA-IR, homeostasis model assessment of insulin resistance.

${ }^{2}$ Mean \pm SD (all such values).

${ }^{3}$ Medians, interquartile ranges in parentheses (all such values).

Table 5: The anthropometric indice and glycolipids of girls in different serum $25(\mathrm{OH}) \mathrm{D}$ groups.

significantly in China. Thus in winter the people had worse vitamin D status. But even in summer, the mean concentration of $25(\mathrm{OH}) \mathrm{D}$ in the study population was only $25.6 \mathrm{ng} / \mathrm{ml}$, with about $1 / 4$ being hypovitaminosis $\mathrm{D}$. The situation was similar to that of female adults in Saudi Arabia [18], which was at lower latitude than Shanghai. Even in Thailand, a tropical country, the prevalence of vitamin D deficiency in adolescents was up to $10 \%$ [19].

The relevancy between vitamin $\mathrm{D}$ and dietary habits was also explored in other researches. Peters et al. [20] found that milk intake was an independent predictor of $25(\mathrm{OH}) \mathrm{D}$. But no association between them was reported by Valeria Hirschler et al. [8]. In this study, the frequency of milk intake differed among vitamin D sufficient and deficient population. But when adjusted by age, gender and other factors, no association was found between the frequency of milk intake and $25(\mathrm{OH}) \mathrm{D}$. The main reason could be that milk fortified with vitamin D is not so popular in China. There are a small number of nature foods that are rich in vitamin $\mathrm{D}$, such as fish oil, fatty fish, and eggs. Except for eggs, other foods are not common in Shanghainese's dietary pattern. So it was acceptable that the common dietary didn't affect the status of vitamin D. By contrast, in Greenland, a decrease in the intake of traditional diet (including fish, seal and whale, etc.) was associated with a decrease in $25(\mathrm{OH}) \mathrm{D}$ [9].

To update, there are large body of researches reported the association between vitamin $\mathrm{D}$ and obesity or metabolic syndrome. In boys whose mean age was $10.5,25(\mathrm{OH}) \mathrm{D}$ was negatively associated with fasting blood glucose in one city $(\mathrm{r}=-0.22)$, while was adversely associated with insulin and HOMA-IR in another city $(\mathrm{r}=-0.25, \mathrm{r}=-0.26$, respectively) [8]. Therefore the author suggested that suboptimal vitamin D was a risk factor of future diabetes. In obese children aged 6-16 year old, $92 \%$ had hypovitaminosis $\mathrm{D}[21]$ and $25(\mathrm{OH}) \mathrm{D}$ was negatively correlated with HOMA-IR $(\mathrm{r}=-0.19, \mathrm{p}=0.001)$ and 2 -h glucose of oral glucose tolerance test $(\mathrm{r}=-0.12, \mathrm{p}=0.04)$. The value of $25(\mathrm{OH}) \mathrm{D}$ for predicting abdominal obesity in Korean youths (12-19-year-old) was determined to be 17.6 $\mathrm{ng} / \mathrm{ml}$ [7]. In adults, the negative association between vitamin $\mathrm{D}$ and insulin was also founded [22]. Furthermore a longitudinal follow-up of about 4000 residents living in Australia found that compared to those who had optimal $25(\mathrm{OH}) \mathrm{D}$ concentration, the odd ratios of people having $25(\mathrm{OH}) \mathrm{D}$ less than $18 \mathrm{ng} / \mathrm{ml}$ and $18-23 \mathrm{ng} / \mathrm{ml}$ to have the onset of metabolic syndrome were up to 1.41 and 1.74 [23].
In spite the accumulating evidences supporting the association of vitamin D with obesity, some researches refuted the correlation. It was presented in Cynthia A Lamendola's study [24] that there were no differences of $25(\mathrm{OH}) \mathrm{D}$ concentration among normal weight and obese ones. And in Poomthavorn P's investigation [19], 25(OH) D concentration had nothing to do with BMI-SDS and insulin. The results we got in this research seemed to be similar to theirs. And no correlation was found between vitamin $\mathrm{D}$ and glucose/insulin, differing from Valeria Hirschler's results [8]. It may due to ethnic difference.

Several limitations of this study should be noticed. First, as it was a cross-sectional study, the risk factors of vitamin D deficiency found could not be determined to be the causalities. Second, we had no information on sun exposure and time spent outdoors.

\section{Conclusion}

In conclusion, the results of this study suggested worrying prevalence of vitamin D deficiency. The risk factors of Hypovitaminosis $\mathrm{D}$ were determined to be female, older age and winter. 25(OH)D concentration was not associated with BMI, WC, NAFLD. Therefore, advocacy of more sun exposure and vitamin D supplementation should be considered in adolescent health promotion. For adolescents having heavy school work and few opportunities doing outdoor sports in Shanghai, vitamin D supplements may need to be applied routinely.

\section{Acknowledgement}

We gratefully acknowledge the cooperation of Shanghai Xuhui and Huangpu District Education Bureau and the teachers in the fifteen schools. We also were grateful to Qing Lu, Dongyong Yan and Ye Zhu for their technical assistance.

The authors' contributions were as follows--YMP and ZYZ were responsible for the initial conception and design of the study. CDG, QLW, ZC, DZ carried out the survey. CDG contributed to the statistical analysis and interpretation data and wrote the first draft of the paper. All authors contributed to the critically revision of the article and approved the final published version to be published.

Funding was provided by the National Key Technology R\&D Program during the 11th Five-year Plan Period of China (2009BAI80B03).

\section{References}

1. Bouillon R, Carmeliet G, Verlinden L, van Etten E, Verstuyf A, et al. (2008) Vitamin $D$ and human health lessons from Vitamin D Receptor Null Mice. Endocrine Rev 29: 726-776.

2. Alco G, Igdem S, Dincer M, Ozmen V, Saglam S, et al. (2014) Vitamin D levels in patients with breast cancer: importance of dressing style. Asian Pac J Cancer Prev 15: 1357-1362.

3. Wahono CS, Rusmini $\mathrm{H}$, Soelistyoningsih D, Hakim R, Handono K, et al (2014) Effects of $1,25(\mathrm{OH})_{2} \mathrm{D}_{3}$ in immune response regulation of systemic lupus erithematosus (SLE) patient with hypovitamin D. Int J Clin Exp Med 7: 22-31.

4. Checkley W, Robinson CL, Baumann LM, Hansel NN, Romero K, et al. (2014) 25-hydroxy vitamin D levels are associated with childhood asthma in a population-based study in Peru. Clin Exp Allergy 45: 273-282.

5. Holick MF, Chen TC (2008) Vitamin D deficiency: a worldwide problem with health consequences. Am J Clin Nutr 87: S1080-S1086.

6. Stoian CA, Lyon M, Cox RG, Stephure DK, Mah JK (2011) Vitamin D concentrations among healthy children in Calgary, Alberta. Paediatr Child Health $2011 ; 16: 82-86$.

7. Nam GE, Kim do H, Cho KH, Park YG, Han KD, et al. (2012) Estimate of predictive cut-off value for serum25-hydroxyvitamin $D$ reflecting abdominal obesity in Korean adolescents. Nutrition Research 32: 395-402.

8. Hirschler V, Maccallini G, Aranda C, Fernando S, Molinari C (2013) Association of vitamin $D$ with glucose levels in indigenous and mixed population Argentinean boys. Clinical Biochemistry 46: 197-201.

9. Andersen S, Laurberg P, Hvingel B, Kleinschmidt K, Heickendorff L, et al (2013) Vitamin D status in Greenland is influenced by diet and ethnicity: a 
Citation: Gong C, Chen Z, Wu Q, Zhang D, Zhao Z, et al. (2015) Risk Factors of Hypovitaminosis D in Adolescents, Shanghai, China: A CrossSectional Study. J Nutr Disorders Ther 5: 158. doi:10.4172/2161- 0509.1000158

population-based survey in an Arctic society in transition. Br J Nutr 109: 928935.

10. Zhu Z, Zhan J, Shao J, Chen W, Chen L, et al. (2012) High prevalence of vitamin $D$ deficiency among children aged 1 month to 16 years in Hangzhou, China. BMC Public Health 12: 126.

11. Foo LH, Zhang Q, Zhu K, Ma G, Hu X, et al. (2009) Low Vitamin D Status Has an Adverse Influence on Bone Mass, Bone Turnover, and Muscle Strength in Chinese Adolescent Girls. J Nutr 139: 1002-1007.

12. Gong CD, Wu QL, Chen Z, Zhang D, Zhao ZY, et al. (2013) Glycolipid metabolic status of overweight/obese adolescents aged 9- to 15-year-old and the BMISDS/BMI cut-off value of predicting dyslipidemiain boys, Shanghai, China: a cross-sectional study. Lipids in Health and Disease 12: 129-137.

13. Cole TJ, Bellizzi MC, Flegal KM, Dietz WH (2000) Establishing a standard definition for child overweight and obesity worldwide: international survey. BMJ 320: 1240-1243.

14. Ji CY, Sung Ry, Ma GS, Ma J, He ZH, Chen TJ (2010) Waist circumference distribution of Chinese school-age children and adolescents. Biomde Environ Sci 23: 12-20.

15. Li H, Ji CY, Zong XN, Zhang YQ (2009) Body mass index growth curves for Chinese children and adolescents aged 0-18 years. Chin J Pediatr 47: 493-498.

16. Shannon A, Alkhouri N, Carter-Kent C, Monti L, Devito R, et al. (2011) Ultrasonographic quantitative estimation of hepatic steatosis in children with NAFLD. J Pediatr Gastroenterol Nutr 53: 190-195.

17. Group of China Obesity Task Force (2004) Body mass index reference norm for screening overweight and obesity in Chinese children and adolescents Chin J Epidemiol 25: 97-102.

18. Kanan RM, AI Saleh YM, Fakhoury HM, Adham M, Aljaser S, et al. (2013) Yearround vitamin $D$ deficiency among Saudi female out-patients. Public Health Nutrition 16: 544-548.

19. Poomthavorn $P$, Saowan $S$, Mahachoklertwattana $P$, Chailurkit $L$, Khlairit $P$ (2012) Vitamin D status and glucose homeostasis in obese children and adolescents living in the tropics. Int J Obes 36: 491-495.

20. Peters BS, dos Santos LC, Fisberg M, Wood RJ, Martini LA (2009) Prevalence of vitamin D insufficiency in Brazilian adolescents. Ann Nutr Metab 54: 15-21.

21. Olson ML, Maalouf NM, Oden JD, White PC, Hutchison MR (2012) Vitamin D deficiency in obese children and its relationship to glucose homeostasis. J Clin Endocrinol Metab 97: 279-285.

22. Brenner DR, Arora P, Garcia-Bailo B, Wolever TM, Morrison H, et al. (2011) Plasma vitamin $D$ levels and risk of metabolic syndrome in Canadians. Clin Invest Med 34: E377.

23. Gagnon C, Lu ZX, Magliano DJ, Dunstan DW, Shaw JE, et al. (2012) Low serum 25 -hydroxyvitamin $D$ is associated with increased risk of the development of the metabolic syndrome at five years: results from a national, populationbased prospective study (The Australian Diabetes, Obesity and Lifestyle Study: AusDiab). J Clin Endocrinol Metab 97: 1953-1961.

24. Lamendola CA, Ariel D, Feldman D, Reaven GM (2012) Relations between obesity, insulin resistance, and 25-hydroxyvitamin D. Am J Clin Nutr 95: 10551059. 